\title{
Hemoglobin Variant Measurement
}

National Cancer Institute

\section{Source}

National Cancer Institute. Hemoglobin Variant Measurement. NCI Thesaurus. Code C103845.

A test to measure the variants of hemoglobin. 